\title{
Cult Statuary in the Judean Temple at Yeb
}

\author{
Collin Cornell \\ Emory University, Atlanta, Georgia \\ collin.cornell@emory.edu
}

\begin{abstract}
A revisitation of the Yeb archives with an eye to the question of cult statuary. The present article inventories the state of the question and makes several constructive suggestions. Its primary contributions are: to address the Yeb evidence, even preliminarily, to the debate over Yhwh statuary in the Jerusalem temple; to make a fresh interpretation of TAD A4.7/8; and to reread other key textual data for information about statuary.
\end{abstract}

\section{Keywords}

aniconism - Jewish studies - cult statuary - early Judaism

\section{Introduction}

In the year $410 \mathrm{BCE}$, a man named Yedoniah wrote to the high priest of Jerusalem. Yedoniah was an official — and possibly the high priest—for c. 3,00o Judeans living on an island called Yeb in the Nile at the southernmost border

* My thanks to Brent A. Strawn for leading the independent study out of which this paper grew, and for reading and commenting on several drafts; thanks as well to Jacob L. Wright for his feedback and encouragement. 
of Egypt, ${ }^{1}$ then a part of the Persian Empire. ${ }^{2}$ The high priest in Jerusalem at that time was Yohanan, a successor to Yoyada cited in the biblical book of Nehemiah (12:22). ${ }^{3}$ Yedoniah sought help from this biblically mentioned high priest: that year, Egyptians had destroyed the temple of Yhwh on the island Yeb, and the Judeans there wished to rebuild.

Ten years later in $400 \mathrm{BCE},{ }^{4}$ this same official Yedoniah received donations of silver from the Judean community on Yeb. The opening line of an administrative document indicates that the donations of silver were dedicated to "the god Yhw."5 But the conclusion of this same document says that Yedoniah allocated the donations to three entities: Yhw, Ašimbethel, and Anathbethel. ${ }^{6}$ The meaning of the final two names is disputed. They may designate other gods worshipped at Yeb besides Yhw, thereby showing an outright "syncretism"

1 Ernst Axel Knauf, "Elephantine und das vor-biblische Judentum," in Religion und Religionskontakte im Zeitalter der Achämeniden, ed. Reinhard G. Kratz, vwGT 22 (Gütersloh: Gütersloher Verlagshaus, 2002), 179-88, here 181. In secondary literature, the island is more commonly called "Elephantine," from Greek $\varepsilon^{\lambda} \varepsilon \dot{\varphi} \varphi \alpha \varsigma$, meaning "elephant." I have chosen to use the place name "Yeb" because it hews closer to the designation used in the Aramaic archives, i.e., $y b$ (reflecting Egyptian 'ibw, also meaning "elephant"). Cf. Reinhard G. Kratz, "The Second Temple of Jeb and of Jerusalem," in Judah and the Judeans of the Persian Period, ed. Oded Lipschits and Manfred Oeming (Winona Lake, IN: Eisenbrauns, 2006), 247-64.

2 For an overview of the Persian rule in Egypt, see Heike Sternberg-el Hotabi, "Die persische Herrschaft in Ägypten," in Religion und Religionskontakte im Zeitalter der Achämeniden, 111-50.

3 For a judicious review of Yohanan's succession, see James C. VanderKam, From Josephus to Caiaphas: High Priests after the Exile (Minneapolis: Fortress, 2004), 53-63.

4 On the dating of the donation list, see $\mathrm{n}$. 43 below. For a comprehensive chronology of events and documents from Yeb, see Angela Rohrmoser, Götter, Tempel und Kult der Judäo-Aramäer von Elephantine: Archäologische und schriftliche Zeugnisse aus dem perserzeitlichen Ägypten, AOAT 396 (Münster: Ugarit-Verlag, 2014), 434-36.

5 TAD C3.15:1. "Yhw" is the local orthography for Yhwh. On this issue of the spelling of the divine name in the Yeb archive, see Bob Becking, "Die Gottheiten der Juden in Elephantine," in Der eine Gott und die Götter: Polytheismus und Monotheismus im antiken Israel, ed. Manfred Oeming and Konrad Schmid, ATANT 82 (Zurich: TVZ, 2003), 203-26, here 209; Rohrmoser, Götter, 111-18; Bezalel Porten, Archives From Elephantine: The Life of an Ancient Jewish Military Colony (Berkeley: University of California, 1968), 105-6. References to TAD throughout the present study abbreviate Bezalel Porten and Ada Yardeni, Textbook of Aramaic Documents from Ancient Egypt, 4 vols. (Jerusalem: Hebrew University, Department of the History of the Jewish People, 1986-1999).

6 TAD C3.15:123-128. 
of Judeans there. ${ }^{7}$ On another interpretation, however, at least one of these names besides Yhw does not refer to another god, but to a cult statue present within the Yhw temple. ${ }^{8}$

How likely is this possibility - that there was cult statuary in the Judean Yhw temple on Yeb? And what might this possibility mean for the study of early Judaism? The present study briefly inventories the state of these questions and makes several constructive suggestions. Its primary contributions are: to address the Yeb evidence, even preliminarily, to the debate over Yhwh statuary in the Jerusalem temple; to make a fresh interpretation of TAD A4.7/8; and to reread other key textual data with an eye targeted to cult statuary.

\section{Importance of the Question for Early Judaism}

As early as 1929, Sigmund Mowinckel broached the idea that there was a cult statue in the first Jerusalem temple. ${ }^{9}$ After lying dormant for decades, this proposal resurfaced vigorously in the $1990 .^{10}$ Its main argument is comparative:

For this perspective, see, for example, the earlier work of Albert Vincent, La religion des Judéo-Araméens d'Éléphantine (Paris: Geuthner, 1937), or the judgment of Bezalel Porten (e.g., his section entitled, "Jewish Syncretism?" in Archives, 173-79, or his article, "The Religion of the Jews of Elephantine in Light of the Hermopolis Papyri," JANER 28 [1969]: 116-21, here 121). Porten downplays but still recognizes syncretism at Yeb. See also Hans-Joachim Stoebe for a qualified view of what was syncretistic at Yeb ("Überlegungen zum Synkretismus der jüdischen Tempelgemeinde in Elephantine," in Beiträge zur Kulturgeschichte Vorderasiens: FS Rainer Michael Boehmer, ed. Uwe Finkbeiner [Mainz: von Zabern, 1995], 619-26).

8 See, for example, Becking: "Anath in Anath-Jahô und Anath-Bethel verweist meines Erachtens auf ein weibliches Kultsymbol" ("Gottheiten," 224). Or Urs Winter, who identifies these two names alongside Yhw in the donation list as "weiblichen Hypostasen JHWs" (Frau und Göttin: Exegetische und ikonographische Studien zum weiblichen Gottesbild im Alten Israel und in dessen Umwelt, ово 53 [Göttingen: Vandenhoeck \& Ruprecht, 1983], 508).

9 Sigmund Mowinckel, "A quel moment le culte de Yahvé à Jérusalem est-il officiellement devenu un culte sans images?" RHPR 9 (1929): 197-216.

10 See, first and foremost, Tryggve Mettinger, No Graven Image? Israelite Aniconism in its Ancient Near Eastern Context, свот 42 (Stockholm: Almqvist \& Wiksell, 1995); cf. also Herbert Niehr, "In Search of Yнwh's Cult Statue in the First Temple," in The Image and the Book: Iconic Cults, Aniconism, and the Rise of Book Religion in Israel and the Ancient Near East, ed. Karel van der Toorn, свет 21 (Leuven: Peeters, 1997), 73-95; Christoph Uehlinger, "Anthropomorphic Cult Statuary in Iron Age Palestine and the Search for Yahweh's Cult 
virtually all of Israel's cognate cultures practiced religion by venerating and processing cult statues. ${ }^{11}$ Scholars also identify memories of cult statuary preserved in Israel's own literature, e.g., in biblical psalms that speak of "seeing Yhwh" or "Yhwh entering" the temple..$^{12}$ The language of these psalms seems to presume a visible, mobile presence of Yhwh such as would be the case if Yhwh were worshipped by a statue. Others argue from Assyrian documents that may refer to the seizure of Israelite cult images. ${ }^{13}$

The possibility that the first temple housed a Yhwh statue contravenes a common perception of Judaism: that it is primordially imageless, or "aniconic." The most important contributor to this perception is the Decalogue, whose second commandment prohibits the manufacture of images (Deut 5:8; cf. Exod 20:4). That is, in the Bible's presentation, the creation of Israel as such at Sinai coincides with the proscription against statuary. This sense of the image ban as a constitutive principle of Judaism endures through the Talmud and

Images," in The Image and the Book, 97-155; Angelika Berlejung, Die Theologie der Bilder: Das Kultbild in Mesopotamien und die alttestamentliche Bilderpolemik unter besonderer Berücksichtigung der Herstellung und Einweihung der Statuen, ово 162 (Göttingen: Vandenhoeck \& Ruprecht, 1998), 286-314; Othmar Keel, Die Geschichte Jerusalems und die Entstehung des Monotheismus, оLB 4/1-2 (Göttingen: Vandenhoeck \& Ruprecht, 2007), 305 .

11 See Uehlinger, "Anthropomorphic," 99-122 for a detailed treatment of the material evidence for anthropomorphic cult statuary in ancient Israel. Niehr writes, "the assumption of a cult statue is the only thesis that fits the character of the Jerusalem temple as an ancient Near Eastern temple. How otherwise would Yahweh be present in his sanctuary if not by virtue of his statue?" ("In Search," 91). Against this, however, see Nadav Na'aman, "No Anthropomorphic Graven Image: Notes on the Assumed Anthropomorphic Cult Statues in the Temples of YнwH in the Pre-Exilic Period," UF 31 (1999): 391-415.

12 Niehr lists as the main arguments for an iconic first temple ritual the psalms of "seeing," the practice of processions, Yahweh's "ascension" to the throne, the shewbreads, and the divine visions of the pre-exilic and exilic prophets ("In Search," 91). Note also Oswald Loretz, Leberschau, Sündenbock, Asasel in Ugarit und Israel: Leberschau und Yahwehstatue in Ps 27, Leberschau in Ps 74, UBL 3 (Altenberge: cis-Verlag, 1985), 73-75.

13 See esp. Bob Becking, "Assyrian Evidence for Iconic Polytheism in Ancient Israel," in van der Toorn, The Image and the Book, 157-71; also, Christoph Uehlinger, “.... und wo sind die Götter von Samarien?' Die Wegführung syrisch-palästinischer Kultstatuen auf einem Relief Sargons II. in Horsabat/Dur-Sharrukin," in "Und Mose schrieb dieses Lied auf..." Studien zum Alten Testament und zum Alten Orient: FS Oswald Loretz, ed. Manfred Dietrich and Ingo Kottsieper, AOAT 250 (Münster: Ugarit-Verlag, 1998), 739-76; Uehlinger, "Anthropomorphic," 124-27; and Karel van der Toorn, "Recent Trends in the Study of Israelite Religion," in Modern Societies and the Science of Religions: Studies in Honor of Lammert Leertouwer, ed. Gerard A. Wiegers, sH R 95 (Leiden: Brill, 2002), 223-43, here 236. 
medieval period, well into modern Judaism and its commentators. ${ }^{14}$ See, for example, the dictum of nineteenth-century Jewish historian Heinrich Graetz, that "paganism sees its god, [but] Judaism hears Him."15

Historical criticism, on the other hand, holds that the image ban represents a late achievement of the Persian period rather than a basic inheritance from the Mosaic past. ${ }^{16}$ This view does not undermine an aniconic definition of Judaism so much as it places the origins of Judaism on rather more ecumenical grounds. Judeans ${ }^{17}$ at first likely thought about and worshipped Yhwh in much the same way as their neighbors worshipped their gods-with images. What is shared preceded what is distinctive. ${ }^{18}$

14 See, for example, Leora Batnitsky, "The Image of Judaism: German-Jewish Intellectuals and the Ban on Images," JSQ 11 (2004): 259-81.

15 Structure of Jewish History and Other Essays, ed. Ismar Schorsch (New York: Jewish Theological Seminary of America, 1975), 68. Quoted in Kalman P. Bland, The Artless Jew: Medieval and Modern Affirmations and Denials of the Visual (Princeton: Princeton University Press, 2000), 21. Cf. the nearly identical sentiment of Martin Buber, who wrote that "der Jude des Altertums mehr Ohrenmensch als Augenmensch ist" (Jüdische Künstler [Berlin: Jüdischer Verlag, 1903], 7); or Abraham Joshua Heschel, who claimed that "Judaism has rejected the picture. [Its] only indispensable object is a Scroll" (The Wisdom of Heschel [New York: Farrar, Straus and Giroux, 1975], 241).

16 For a brief account of modern scholarship, see Ryan P. Bonfiglio, "Images and the ImageBan in the Hebrew Bible and Israelite Religion," Oxford Biblical Studies Online, http:// www.oxfordbiblicalstudies.com/resource/image.xhtml. Cf. also Christoph Dohmen, Das Bilderverbot: Seine Entstehung und seine Entwicklung im alten Testament, 2nd ed., вв в 62 (Frankfurt am Main: Athenäum, 1987).

17 As Bob Becking observes, the "Aramaic noun [yhwdy'] can be rendered as 'Jewish' as well as 'Yehudite' [or 'Judean']" ("Yehudite Identity in Elephantine," in Judah and the Judeans in the Achaemenid Period: Negotiating Identity in an International Context, ed. Oded Lipschits et al. (Winona Lake, IN: Eisenbrauns, 2011], 403-19, here 404). Deciding by which term to translate the Aramaic self-designation is deeply hermeneutical. Most treatments of religion at Yeb translate the word as "Jews"/"Jewish," thereby associating citizens of Yeb with (the religion) Judaism. I concur with Becking, who reserves these descriptors for a later period, and sees the word $y h w d y^{\prime}$ as a more regional/ethnic reference, i.e., meaning "coming from the Persian province of Yehud" (“Gottheiten," 208). So Becking: “Jewish' seems to be an anachronism for fifth-century в Се Yahwism. The Yehudites [of Yeb] were not (yet) Jews" ("Yehudite Identity," 414). Cf. also Reinhard G. Kratz, "Judean Ambassadors and the Making of Jewish Identity: The Case of Hananiah, Ezra, and Nehemiah," in Judah and the Judeans in the Achaemenid Period, 421-44, but esp. 421-24 for the question of "Judeans" versus "Jews" at Yeb.

18 Even if historical criticism late-dates the development of what is distinctive to Judaism, the above insight - that what is shared precedes what is distinctive — follows the contour of biblical narrative itself. See, for example, R. W. L. Moberly's remarks on Genesis, that it 
The possibility that Judeans venerated a Yhwh statue on the island of Yeb only underscores this point: even in the era after the Babylonian golah when deuteronomistic theology was probably ascendant, communities of Judeans in good standing may still have practiced an iconic form of Yahwism. If it could be established that Judeans at Yeb worshipped Yhw with a cult statue, this would also have important ramifications for the debate about statuary in the Jerusalem temple. Contrariwise, if the Yhw temple at Yeb was aniconic, this would suggest that it was possible in a Judean temple contemporary with the first Jerusalem temple to worship Yhwh without an image. In either case, the witness of Yeb matters for the statuary debate if (and only if) the religion of Judeans at Yeb comprises a form of Yahwism continuous with that of Yehud. If, alternately, the religion of Judeans at Yeb is discontinuous with the Yahwism of Yehud, embodying a syncretistic "pidgin," this reduces its value for the debate over Yhwh statuary in the Levant.

In my estimation, the Yeb Judeans show several signs of discontinuity with Judeans in Yehud. They sometimes call themselves "Aramaeans," they intermarry with local Egyptians, they swear by other gods, and their greeting in letters is polytheistic. ${ }^{19}$ Most likely, Judeans in Yehud would not have taken up these practices (e.g., Ezra 9). ${ }^{20}$ After 407 BCE, Judeans on Yeb also refrained

"depicts no antagonism between the patriarchs and the religious practices of the native inhabitants of Canaan" (The Old Testament of the Old Testament: Patriarchal Narratives and Mosaic Yahwism, овт [Minneapolis: Fortress, 1992], 89). Moberly can also write of the "ecumenical bonhomie" characteristic of the ancestors' religion in Genesis (ibid., 104). Cf. how a text like Jubilees brings the ancestors' religion into conformity with Sinai, e.g., Abraham's rejection of idols in 12:1-8.

19 On the problem of the Yeb Judeans' self-designation as "Aramaeans" (TAD B2.10), see Peter Bedford, "Jews at Elephantine," Australian Journal of Jewish Studies 13 (1999): 6-23. On the intermarriage of Yeb Judeans, see TAD B3.3, in which the Judean free man Ananiah marries the Egyptian slave Tamut; cf. Porten, Archives, 205-13. For more general remarks on intermarriage at Yeb, see Porten, "The Religion of the Jews of Elephantine," 121. On the Yeb Judeans' practice of taking oaths in the name of gods beside Yhw, see for example TAD B7.3, in which the man Menahem swears by the deity name Anath-Yhw (line 3; see discussion below). The Judeans at Yeb write as a common epistolary benediction, "may the gods seek the peace of [PN, addressee]," e.g., TAD A4.1, A4.2, A4.4, or even, "may all the gods seek..." as in TAD A3.7. Perhaps, as per Porten, this may have been completely conventional, like a Jew sending another Jew a Christmas card (Archives, 174). Or not!

In fact, this is difficult to determine, and assumes the ascendancy of deuteronomistic theology in Jerusalem and Yehud during this time, e.g., the normativity of biblical prohibitions on worshipping or swearing by other gods and intermarrying foreigners. But other Judeans (in the diaspora, at least) were swearing by other gods and intermarrying foreigners; for information about Judeans in Babylonia in the fifth and sixth centuries, 
from animal sacrifice, quite unlike the Jerusalem temple. ${ }^{21}$ TAD A4.1, "the Passover Letter," details instructions from the Persian emperor Darius II on how the Yeb community should celebrate Passover. Passover is often seen as one of the cornerstones of religion in Persian Yehud (e.g., Ezra 6). If the Judean community at Yeb was not celebrating Passover before 419 в letter), this would demarcate them strongly from their kin in Yehud.

Despite these discontinuities, the two communities of Judeans also show a strong contiguity. The size and age of the Yeb community support their relative importance. Ernst Axel Knauf estimates that 1.5\% of all Judeans then living were resident at Yeb. ${ }^{22}$ The duration of the Judean community at Yeb is disputed, but TAD A4.7/8 refers to the temple's existence in Cambyses's time, over 118 years before the letter's composition; the Yeb archives as a whole attest the community's presence throughout the 5 th century. For potentially several centuries, then, the Judean community at Yeb deliberately upheld their Judean identity in a foreign environment. ${ }^{23}$ The extant correspondence between Yehud and Yeb amply demonstrates a mutual recognition of kinship. ${ }^{24}$

see Tero Alstola, “On the Road: Judean Royal Merchants in Babylonia” (paper presented at the Annual Meeting of SBL, San Diego, CA, 11 November 2014). The rate of intermarriage between Judeans at Yeb and other groups in the area was limited (Porten, Archives, 174.). In TAD A4.9, the governors of Yehud and Samaria, Bagohi and Delaiah, apparently limit the sacrifices in the Yeb temple to meal offering and incense (line 9). The reply from Yedoniah in TAD A4.10 makes it even clearer what had become verboten: "sheep, oxen, and goats are not offered as burnt sacrifice there" (line 9). For a comprehensive treatment of the so-called Brandopferverbot at Yeb, see Rohrmoser, Götter, 214-18. On the question of whether TAD A4.10 represents a reply to Bagohi or a letter to someone else, see Arthur Cowley, Aramaic Papyri of the Fifth Century BC (Oxford: Clarendon, 1923), 124; references to AP in the present study indicate Cowley's edition and its numeration. On the issue of Delaiah as acting governor, see Jeremiah W. Cataldo, A Theocratic Yehud? Issues of Government in a Persian Province, Lнвотs 498 (New York: T\&T Clark, 2009), 83.

22 Knauf, "Elephantine," 182.

23 Reinhard G. Kratz, "Elephantine und Alexandria: nicht-biblisches und biblisches Judentum in Ägypten," in Alexandria, ed. Tobias Georges et al., comes 1 (Tübingen: Mohr Siebeck, 2013), 103-208, here 194. See also Becking, "Gottheiten," 208.

24 Hananiah, a Judean from Yehud or the Babylonian golah, calls the Yeb community "brothers" in TAD A4.1, line 1. Reinhard G. Kratz writes of the correspondence between Yeb and Yehud: "The close connections kept by the Jewish garrison not only with the Persian authorities but also with the ruling people in Jerusalem and Samaria in matters regarding the rebuilding of the temple seem to suggest that, even for their own time, they were not exceptional. Rather, they seem to have been compatible with the Jewry represented by the leading figures in Jerusalem and Samaria to whom they addressed their letters" ("Temple and Torah: Reflections on the Legal Status of the Pentateuch between 
A judicious reading of the above data warrants a balanced conclusion: the Judeans at Yeb were distinctive from Judeans in the homeland. At the same time, they were kin to them, to an extent such that if it were proven Judeans at Yeb worshipped Yhw with cult statuary, it would lend important support to its presence in the first Jerusalem temple. Three sections below comment on (the) three key textual evidences from the Yeb archives relevant to the question of cult statuary. ${ }^{25}$

\section{TAD A4.7/8: Letter of Petition ${ }^{26}$}

TAD A.4.7/8 are two drafts of a letter of petition, written by Yedoniah to Bagohi, the governor of Yehud. ${ }^{27}$ These two draft letters are important to the question of cult statuary at Yeb because they contain a detailed inventory of the Yeb temple, lines 8-13 of A4.7 and lines 7-11 of A4.8. These passages contain no obvious mention of cult statuary. For scholarship proposing that the Yeb temple housed statuary-including the present study - the omission is a problem in need of explanation. One explanation is that, despite appearances, TAD

Elephantine and Qumran," in The Pentateuch as Torah: New Models for Understanding Its Promulgation and Acceptance, ed. Gary N. Knoppers and Baruch M. Levinson [Winona Lake, IN: Eisenbrauns, 2007], 77-103, here 87). TAD A4.7/8 refers to Bagohi's "obligees and friends here in Egypt" (lines 24/23, țtk wrhmyk zy tnh bmșryn). Of course, a letter of petition such as Yedoniah's should be expected to "play up" the friendship between people of Yeb and Bagohi.

25 Rohrmoser reviews the archaeological data for the Yhw temple in some detail (Götter, 15385 ), but determines ultimately that they stand mute concerning the existence of statuary, and that textual evidences must provide the basis for discussion (Götter, 187). The present study concurs with her methodological decision.

26 AP 30; text, translation, and commentary in Cowley, Aramaic Papyri, 108-19; Rohrmoser, Götter, 397-407; Porten, Archives, 290-93; James M. Lindenberger, Ancient Aramaic and Hebrew Letters, and ed., ed. Kent Harold Richards, sbl Writings from the Ancient World 14 (Leiden: Brill, 2003), 72-76; "Petition for Authorization to Rebuild the Temple of Yaho," trans. H. L. Ginsberg (ANET, 491-92); plates in Eduard Sachau, Aramäische Papyrus und Ostraka aus einer jüdischen Militär-kolonie zu Elephantine: altorientalische Sprachdenkmäler des 5. Jahrhunderts vor Chr., 2 vols (Leipzig: Hinrichs, 1911), pls. 1, 2; bibliography in An Aramaic Bibliography, Part I: Old, Official, and Biblical Aramaic, ed. Joseph A. Fitzmyer et al. (Baltimore: Johns Hopkins, 1992), 63-65.

27 Yedoniah claims that he sent much the same letter to Delaiah and Shemaiah, the sons of Sanballat the governor of Samaria (lines 29/29). He also says that he wrote previously, "at the time that this evil was done to us" (lines 18/17, i.e., closer to $410 \mathrm{BCE}$ ) to Bagohi and to the high priest Yohananan and to the Judean nobility. 
A.4.7/8 contains important clues to the presence of cult statuary in the Yeb temple. The present study seeks a different explanation for Yedoniah's silence about statuary, namely, in the letter's genre.

After greeting Bagohi, Yedoniah tells of the destruction of the Yhw temple. The Egyptian satrap Arsames was away at the court of Darius II in Susa. The reason for his absence is unknown. While he was away, the Egyptian priests of Khnum plotted with Widranga, the regional Persian authority, who delegated his son Nephaina, the garrison commander across the Nile in Syene, to demolish the Yhw temple. ${ }^{28}$ With a troop of Egyptian soldiers, Nephaina razed the temple, burning whatever was burnable and stealing its valuables. Lines $7 \mathrm{~b}-11$ of the second draft, supplemented from the first, read:

Thereafter that Nephaina led the Egypt[ians with other troops. They came to the fortress of Yeb with] their weapons. They went into that temple, they demolished it to the ground, and the pillars of s[tone which were there, they shattered them. Also, they destroyed] five great gateways, built of hewn stone, which were in that temple. [And the standing doors, and the] bronze hinges of those doors, and the roof of that temple, all o[f it] cedarwood, with the $\mathrm{r}$ [est of the fittings and the other (things) which were there, all of these] they burned with fire. But the gold and silver basins and (other) things wh [ich were in that temple, all of these they took and] made [their own]. ${ }^{29}$

Several commentators argue that the petition refers obliquely to cult statuary by its repeated phrase, "the other (things) which were there" (w'hrn zy tmh hwh, TAD A4.7:11, 12, reconstructed in A.4.8:10). Rohrmoser writes: "The double occurrence of 'the other things that were there' in the list in TAD A4.7, 11f. includes one or more statues in the temple." ${ }^{30}$ On this reading, Yedoniah implies the cult statuary without spelling it out, so as to avoid offending against

28 Many reasons have been suggested for the temple's destruction, including the displeasure of the priests of Khnum (a ram deity) with ram sacrifices in the Yhw temple (Porten, Archives, 286), and/or that the rivalry between temples constituted a threat to the imperial peace, such that Widranga agreed to destroy the Judean temple (Rohrmoser, Götter, 258). TAD A4.5 says that the Egyptian priests of Khnum gave silver and goods to Widranga (line 4), but it is unclear there if this bribery effected the temple destruction or some other misdeed.

29 My translation. The italics reflect the critical phrases.

30 Rohrmoser, Götter, 191. "[D]ie doppelte Nennung von 'was auch immer dort war' in der Aufzählung der Verluste in TAD A.4.7, 11f. schließt eines oder mehrere Standbilder im Tempel mit ein" (My translation). 
Jerusalemite theology. Nonetheless, Yedoniah wishes Bagohi to know that the Egyptian troop stole the valuable temple paraphernalia-including the cult statuary - and used it for themselves, or melted it down. This interpretation makes sense of the petition letter if one assumes already that there was cult statuary in the Yeb temple. But its postulate that the Jerusalem temple authorities would have objected to cult statuary at Yeb is at least open to dispute. It is unknown whether the image ban was yet in effect in Jerusalem. ${ }^{31}$ Evidently, too, the Jerusalem priests did not object to (or could not enforce) the Yeb temple's violation of cult centralization, and so perhaps would not have objected to the Yeb temple's violation of the image ban. Whether Yedoniah would have known about and respected their strictures is another inference. ${ }^{32}$ Furthermore, the repeated phrase in the petition letter could refer just as easily to other detritus from the temple destruction.

It is possible but improbable that the petition letter mentions cult statuary openly. That is, the words it uses for "pillars" (w'mwdy' zy 'bn' zy hww tmh "the

31 Knauf holds that the request of TAD A4.9 to refrain from making animal sacrifices demonstrates that Jerusalem had adopted deuteronomistic thinking about cult centralization and the image ban but lacked authority to promulgate it consistently. He argues that the Judeans at Yeb were aware of this religious outlook in Jerusalem and consequently made a tactful omission [taktvollen Verschweigen] of cult statuary in their petition ("Elephantine," 179). But this assumes either that the Jerusalem priesthood would have been privy to Yedoniah's letter to Bagohi (or one just like it), or that Bagohi was identified with Jerusalemite interests. Neither of these assumptions is certain. Even if a form of the petition were sent to the Jerusalemite priests as TAD A4.7/8 alleges (lines 18/17), it must have looked somewhat different from TAD A4.7/8, since the letter's final appeal to religious merit would hardly play to sacrificial specialists in Jerusalem. Bagohi's allegiance is also contestable. His name could be either Judean or Persian; if Josephus's testimony about him is credible (Ant. 4.457-461), Bagohi was invested in the Jerusalem temple to the extent of plotting to put his favored high priest in power. But he was disinvested in Jerusalemite theology such that he transgressed its protocols by entering the temple as a Gentile, and then taxed its sacrifices. This does not sound like a man who would take offense because Judeans in Yeb were worshipping Yhwh with a cult statue. On the other hand, Yedoniah believed that Bagohi might want to help rebuild the Yeb temple to gain favor from Yhwh.

32 Apparently Yedoniah had no compunction going around the back of the Jerusalemite authorities in another regard: since they remained silent, he sought other benefactors, in Samaria — a rival religious site to Jerusalem! — and in the governor of Yehud, Bagohi. The Yeb leader does not thereby demonstrate a great deal of deference to the religious authorities in Jerusalem. Less likely, maybe Yedoniah lied and never sent a letter to the Jerusalem priests; his claim was a fiction to assure Bagohi that Yedoniah had gone first through proper channels before addressing himself to the governor. 
pillars of stone which were there" [lines 9/8]) could refer to betyls or mașsebot. The pillars have usually been taken as referring to round hewn columns standing either at the façade or in the interior of the temple. ${ }^{33}$ Other Aramaic vocabulary more typically describes betyls, ${ }^{34}$ but there are a few instances where the word Yedoniah uses may designate a betyl. ${ }^{35}$ This interpretation struggles, however, to account for other ways in which the petition apparently adjusts to appease Jerusalemite theology. Knauf notes that Yedoniah has substituted a singular God in his greeting ("the God of heaven," TAD A4.7/8, line 2) for the typical pluralistic salutation ("the gods"). ${ }^{36}$ When the memorandum came back from Bagohi and Delaiah instructing that the reconstructed Yeb temple refrain from offering animal sacrifices (TAD A4.9), Yedoniah and the Yeb priests obeyed (TAD A4.10). Because of this compliance, it becomes harder to think that Yedoniah knew but flaunted the Jerusalemite preference for aniconic worship. Besides this, there are numerous more common ways of referring to cult statuary than by the word ' $m w d$, which has a perfectly satisfactory architectural meaning in the petition letter.

The present study argues that TAD A4.7/8 omits to mention cult statuary because of its genre. Yedoniah does not reference statuary because, when an enemy destroys a temple and seizes its properties, one does not admit to this-at least in the kind of literature that TAD A4.7/8 represents. Yedoniah's petition letter is generically unique. There are other examples in the ancient Near East that remember the despoliation of cult statuary, but unlike these, Yedoniah's letter is pragmatic and non-theological.

The phenomenon of "godnapping" was widespread in the ancient world. ${ }^{37}$ Conquering kings would destroy or steal cult statuary from the temples of

33 Rohrmoser, Götter, 399 .

34 See, for example, Joseph Patrich for the Aramaic vocabulary commonly used for betyls in Nabataean (The Formation of Nabataean Art: Prohibition of a Graven Image Among the Nabataeans [Leiden: Brill, 1990], 52, 53). See also Ziony Zevit, The Religions of Ancient Israel: A Synthesis of Parallactic Approaches (New York: Continuum, 2001), 256-65.

35 See, for example, the Jerusalem Talmud, which says that "a person can enter a synagogue, stand behind a pillar, and pray in an undertone, and the Holy One, blessed be He, hears his prayers" (Ber. 4:1, 9:1). Or again, in the Exodus Rabbah, God says to Abraham, "you stand in the place of the pillar of the world" (2.13). Šabb. 13c11 refers to one who "hews out pillars," that is, as an idolater. All these instances are highly disputable as references to betyls.

36 Knauf, "Elephantine," 187. See n. 19 above.

37 See, for example, Erika Johnson, "Stealing the Enemy's Gods: an Exploration of the Phenomenon of Godnap in Ancient Western Asia" (PhD diss., University of Birmingham, 2011). 
subject peoples. ${ }^{38}$ However, most records of this phenomenon in the ancient Near East come from the side of the victors: Assyrian annals recounting the triumph of their kings. Only exceptionally do instances survive in which the defeated describe the despoliation of their gods. Sumerian city laments are one of the genres that do this, but they are poetic and theological: these laments always conclude with a prayer for restoration and the return of the gods. ${ }^{39}$ Another more proximate example of cult despoliation remembered from the underside is the Hebrew Bible (e.g., 2 Kgs 14:14). ${ }^{40}$ Like the Sumerian city laments, it is deeply rhetorical and theological.

Perhaps the Yeb community interpreted their temple's destruction theologically, as a sign of Yhw's wrath against them. The fact remains, however, that a letter of request to a regional Persian authority could hardly serve as an organ of communal lament and theologizing, as did the Hebrew Bible or the Sumerian laments. As such, a petition may have been a generically inappropriate venue to articulate the loss of cult statuary. We can imagine, for example, that unpreserved memos between Nehemiah and the Persian authorities did not enshrine the communal self-reflection and theological discussion that the Hebrew Bible does. Rhetorically, Yedoniah's letter seeks to persuade Bagohi that the Judean garrison at Yeb are loyal Persian subjects who have experienced a grave offense from the colonized Egyptians, and that rectifying the wrong will result in divine blessing for the Judean governor; the letter does not explore questions of responsibility except as these are discernible on the human plane-which is also where the letter seeks resolution. Even if Yedoniah shared deuteronomistic retributive theology, it would have been rhetorically counterproductive for him to communicate this to Bagohi ("because of our sins, our god(s) abandoned us... but could you please help us out?"). Perhaps, too, Yedoniah and the Judeans of Yeb did not feel their temple's destruction as cataclysmically as the Sumerian laments or the Hebrew Bible; they may have seen it more as a (severe) short-term interruption than a true annihilation of their cult. ${ }^{41}$

38 Hanspeter Schaudig, "Death of Statues and Rebirth of Gods," in Iconoclasm and Text Destruction in the Ancient Near East and Beyond, ed. Natalie Naomi May, o 8 (Chicago: The Oriental Institute of the University of Chicago, 2012), 127 and passim.

39 See the classic work of Margaret W. Green on the typology of Sumerian laments ("Eridu in Sumerian Literature" [PhD diss., University of Chicago, 1975]).

40 See especially Jacob L. Wright, "The Deportation of Jerusalem's Wealth and the Demise of Native Sovereignty in the Book of Kings," in Interpreting Exile: Displacement and Deportation in Ancient and Modern Contexts, ed. Brad E. Kelle et al., Ancient Israel and its Literature 10 (Atlanta: SBL, 2011), 105-30.

41 Peter Bedford, “Jews," 22. 


\section{TAD C3.15: The Donation List ${ }^{42}$}

Another potentially important datum for the question of cult statuary is the much-discussed donation list. The donation list is, according to its own first line, a list of "the names of the garrison of Judeans who gave silver to the God Yhw, 2 shekels per person" (znh šmht hyl' yhwdy' zy yhb ksp lyhw 'lh' lgbr lgbr ksp š). No king is named, although the document opens with a date, "the 3 rd of Phamenoth, 5th year" (line 1). ${ }^{43}$ It also mentions Yedoniah ben Gemaryah, the author of TAD A4.7/8 above, and a leader of the Yeb community (line 120).

A conflict of interpretations surrounds lines 123-128. Here the list of names and contributions reaches a provisional conclusion. These lines recapitulate the month name and the silver from the opening line of the list, but then designate the recipient of the contributions (Yedoniah) rather than its source (the Judean garrison). The text then counts the total of contributions. It allocates the funds to three entities: of 31 karsh and 8 shekels of silver, Yhw receives 12 karsh and 6 shekels, Ašimbethel receives 7 karsh, and Anathbethel receives 12 karsh. After this, (another?) list of contributions commences.

Who are these other named deities? And how are the donations connected with them? Several options are possible. Because the list begins with reference to Yhw, some scholars have seen these other two names as hypostases of Yhw. ${ }^{44}$ That is, the Judeans of Yeb worshipped Yhw by two other named manifestations. For others, the donation list constitutes a case in point for the syncretism of Judeans at Yeb. Because Porten believes the Judeans at Yeb were

42 AP 22; text, translation, and commentary in Cowley, Aramaic Papyri, 65-76; Rohrmoser, Götter, 413-22; Porten, Archives, 160-64; "Contributions to the Cult of Yaho," trans. H. L. Ginsberg (ANET, 491); plates in Sachau, Aramäische Papyrus und Ostraka, pls. 17-20; and bibliography in Fitzmyer, Aramaic Bibliography, 98-99. The document is a palimpsest, Aramaic written over a Demotic text. Its style is cursive and somewhat hasty, and its condition is fragmentary.

43 The meaning of this date is also controverted, and important for interpreting the purpose of the donation list. No king is mentioned. Porten argues on paleographic and onomastic

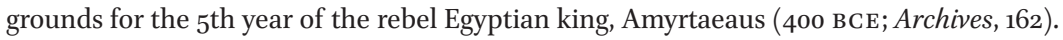
Cowley disbelieves that Yedoniah and the Judean Yeb community would have been so identified with the Egyptian rebellion, and argues that the $5^{\text {th }}$ year is the same as in TAD

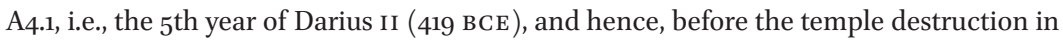
410 вСе (Aramaic Papyri, 66).

44 Porten, Archives, 164. See also Lester L. Grabbe, "Elephantine and the Torah," in In the Shadow of Bezalel: Aramaic, Biblical, and Ancient Near Eastern Studies in Honor of Bezalel Porten, ed. Alejandro F. Botta, CHANE 60 (Leiden: Brill, 2013), 125-35, here 128. 
"primordially compliant with Jerusalem [theology],"45 he argues that these two divine names are not Judean gods, but Aramaean. Judeans did not import multiple gods, but came to worship them as a result of long-term close quarters with Aramaeans on an isolated island. Alternately, Judeans already worshipped these gods when they arrived in Egypt. ${ }^{46}$

The purpose of the moneys collected is also contested. Epstein believed that they were collected for the temple at Jerusalem, but this is unlikely in view of lines 123-28. ${ }^{47}$ Cowley supposes that the contributions were somehow related to "Hananiah's mission... his (re-)institution of (Passover and) Unleaved bread" as part of a "religious revival." ${ }^{\text {" }}$ These funds could also have gone towards regular temple maintenance, like the half-shekel temple tax at Jerusalem. ${ }^{49}$ Others have supposed that the collection was for restoring the temple after its destruction, perhaps for rebuilding its roof. ${ }^{50}$

These interpretations explain the identity of the deity names and give a purpose for the donated silver. But they do not connect these closely. If the silver were given for regular temple maintenance or for rebuilding after destruction, the insertion of three god names is a very elliptical way of indicating this purpose. ${ }^{51}$ Furthermore, the above explanations also fail to make sense of the enormity of the silver, which exceeds that required for normal temple upkeep or even for remaking the temple roof. ${ }^{52}$ Another interpretation of the

45 This is Rohrmoser's assessment of Porten. Original German: "Ursprünglich jerusalemkonforme 'Juden'” (Götter, 195).

46 This is widely held. See, for example, Karel van der Toorn, "Anat-Yahu, Some Other Deities, and the Jews of Elephantine," Numen 39 (1992): 80-101; or Herbert Niehr, "The Rise of Үншн in Judahite and Israelite Religion: Methodological and Religio-Historical Aspects," in The Triumph of Elohim: From Yahwisms to Judaisms, ed. Diana V. Edelman (Kampen: Kok Pharos, 1995), 45-72.

47 J. N. Epstein, "Jahu, AŠmbēthēl und Antbēthēl," ZAW 32 (1912): 139-45.

48 Cowley, Aramaic Papyri, 66.

49 Ibid.

5o Cowley, Knauf, and Rohrmoser all refer to this theory but do not cite it. Cowley dismisses this idea, because the funds are too small. "You cannot build a temple on a half-crown subscription" (Aramaic Papyri, 66). It is unclear on what basis he considers the donations small. See n. 52 .

$5^{1}$ Cf. Rohrmoser's words: "Wäre es für den Aufbau des Tempels verwendet worden, dann ist es unsinnig den Geldbetrag einzelnen Göttern zuzuweisen, obwohl er dann doch wieder im gleichen Topf landet. Auch wäre dann eine Aufteilung nicht in Götter, sondern nach Material und Handwerker am Ende der Liste zu erwarten" (Götter, 198).

$5^{2}$ So Knauf: "Um die Kosten für das gemeinsame Dach ebenfalls nicht" ("Elephantine," 185). Knauf draws attention to the great size of the totaled donations. He does not overtly reference the shekels of Ezra-Nehemiah, but if one assumes any continuity of measure, 
data resolves these difficulties more elegantly: Rohrmoser, expanding earlier arguments by Knauf, proposes that the god names and the large sums together suggest that the silver was given for the restoration of cult statuary which had been destroyed or stolen by Egyptians in 410 BCE. Rohrmoser even speculates about the kind of statue that this much silver could have helped to create. If the statues were completely silver, they would have been somewhat small; if, on the other hand, they had a wooden core, their proportions could have been much larger. ${ }^{53}$

On this reading, the Yhw temple at Yeb housed (at least) three cult statues: two of about equal size representing Yhw and a goddess named Anathbethel, and then a smaller statue representing Ašimbethel. Knauf posits from this that Anath(bethel) was the paredros of Yhw at Yeb, and a "high god(dess)," whereas Ašim was a more minor deity. ${ }^{54}$ This interpretation is open to challenge on grounds of dating; if the donation list precedes the temple destruction in $410 \mathrm{BCE}$, the donations cannot have served to recreate cult statues. ${ }^{55} \mathrm{In}$ my estimation, however, Knauf and Rohrmoser have advanced a creative but satisfying solution to the riddle of the donation list. As such, the donation list stands as an important evidence for the presence of statuary at Yeb.

the 2 shekel donations of TAD $\mathrm{C}_{3} .15$ were indeed demanding. Cf. the annual temple tax of 1/3 shekel in Neh 10:32.

53 Rohrmoser, Götter, 197.

54 "High(goddess)" here translates Rohrmoser's reference to Yhw and Anath as "Hauptgötter" (Götter, 198). Bob Becking argues from the relative marginality of Anath in the Phoenician pantheon at this time that the name in the donation list most likely refers to a "weibliches Kultsymbol" and not to a goddess proper (“Gottheiten," 224). Cf. van der Toorn makes similar observations about the relative obscurity of Anath in the first millennium, and so also would oppose an interpretation like Knauf's above ("Anat-Yahu," 83).

55 In fact, Knauf reverses the direction of this argument, moving from the size of the donations to the likely dating: "die hohe Spendensumme (318 Schekel) erklärt sich leicht, wenn es um Spenden für den Wiederaufbau ging. Damit ist das von Porten vorgeschlagene Datum 401/400 gegenüber der älteren Datierung (420/19) zu favorisieren" ("Elephantine," 185). On the other hand, this interpretation runs up against the difficulty of interpreting the " 5 th year" of line 1 as reckoning from the rebel Egyptian king, Amyrtaeaus. This seems prima facie unlikely given how eager Yedoniah is in TAD A4.5 and A4.7/8 to prove the Yeb community's loyalty to the Persians. 
TAD B7.2: Oath Text ${ }^{56}$

The third potentially important text for the question of cult statuary is TAD B7.2, a juridical document. Its opening line dates it to 18 Paopi in the fourth year of King Artaxerxes. ${ }^{57}$ In it, a man named "Malkiyah son of Yašobyah, an Aramaean, a citizen in Yeb (mhhsn byb)" clears himself of charges made against him by Artafrada. Although Malkiyah calls himself an Aramaean, his personal name and patronymic are clearly Yahwistic ("my king is Yah").

Lines 4-6 specify the accusation: that Malkiyah had forcibly entered Artafrada's house, accosted his wife, and stolen his property. Malkiyah was then questioned; and "an entreaty to the gods came upon [him]" (wmqry' 'l'/hn $m t^{\prime}$ ' $y$ ), i.e., it behooved him to "entreat the gods" by swearing an oath of innocence. In lines 7 and 8, Malkiyah lists the entities by which he swears.

\section{'nh mlkyh 'qr'lk ' hrmbyt'l/'lh' byn [m]qmn 4}

I, Malkiyah, call against you to hrmbyt'l / the god, before the four avengers ${ }^{58}$

This line — and most especially its compound word or phrase hrmbyt' — has been variously translated (and interpreted). Here are the options presented in scholarship, together with their implications for cult statuary.

1. Pierre Grelot translates it as "Herem-Bethel, the god," referring to the "sacred enclosure" of the god Bethel, worshipped at Syene across the river from Yeb. ${ }^{59}$ This interpretation makes the oath-taker and his god distinctively Aramaean — and irrelevant to the issue of cult statuary in the temple on Yeb.

2. Urs Winter translates it as "Herem-Bethel, the god," referring not to any sacred object, but to an hypostasis of the god Bethel. ${ }^{60}$ Unlike Grelot, he

56 AP 7; text, translation, and commentary in Cowley, Aramaic Papyri, 19-21; Rohrmoser, Götter, 423-24; Porten, Archives, 156-58; plates in Sachau, Aramäische Papyrus und Ostraka, pl. 26; and bibliography in Fitzmyer, Aramaic Bibliography, 93-94.

57 It is debated to which Artaxerxes this line refers. Rohrmoser agrees with Porten in dating the text to 18 January $401 \mathrm{BCE}$; Cowley calculates the date to 18 January 461 . For our purpose, this difference of 60 years is immaterial.

$5^{8}$ My translation.

59 Pierre Grelot, Documents arameéns d'Egypte, LAPO 5 (Paris: Cerf, 1972), 93.

6o Frau und Göttin, 501 n. 108. 
sees a divine name rather than a divine space in view. Winter thereby makes the god Bethel, in his hypostasis as Herem-Bethel, a recipient of worship by Judeans on Yeb. But his interpretation is mute with regards to the question of statuary.

3. Karel van der Toorn translates it as "the sacred property of Bethel, the god," i.e., he takes the first term of the compound phrase as referring to an object and not to a deity name. That is, Malkiyah "took an oath by an inviolable object belonging to the god, instead of directly invoking the name of the deity."61 Van der Toorn is more specific and local than Grelot, more physical than Winter. Another gloss he provides for hrmbyt'l is "consecrated cultic utensils." 62 Van der Toorn's interpretation is suggestive for the question of statuary, but perhaps leaves open whether or not it was present.

4. Angela Rohrmoser translates the phrase as, "den geweihten Betyl des Gottes (Jahu)," "the sacred betyl of the God" (Yahu). Rohrmoser alone gives the text a fully Yahwistic sense; she argues that "the God" ('lh') most often indicates Yhw in the Yeb archive. She agrees with van der Toorn in interpreting the first term of the compound phrase as a cult object, but also reads the second term byt'l as referring to a betyl proper and not to a divine name. ${ }^{63}$ Her interpretation bears directly on the cult statuary question: if she is correct, TAD B7.2 attests the presence of an object representing Yhw in the Yeb temple.

In my judgment, the strongest reading of the text's syntax interprets the phrase in question as referring to a cult object or appurtenance. The parallel of TAD B.7.3 strongly bears this out. In this formally similar oath text, the Judean oathtaker Menahem son of Šallum (line 1) swears by three entities: 6 hl rm bmsgd' wbintyhw (line 3). ${ }^{64}$ If the first and last terms are controversial, the middle term is not (msgd, "sanctuary"). ${ }^{65}$ Van der Toorn argues from this that the

$61 \quad$ Karel van der Toorn, "Herem-Bethel and Elephantine Oath Procedure," ZAW 98 (1986): $282-85$, here 283 .

62 Ibid., 285. hrm on this reading is adjectival, modifying byt'l. On this possibility, see Becking, "Gottheiten," 220.

63 Rohrmoser, Götter, 149.

64 AP 44; text, translation, and commentary in Cowley, Aramaic Papyri, 149-50; Rohrmoser, Götter, 425-26; Porten, Archives, 154-56; plates in Sachau, Aramäische Papyrus und Ostraka, pl. 32; and bibliography in Fitzmyer, Aramaic Bibliography, 94.

65 Porten translates the word etymologically as "place of prostration," but also explains it as the "altar precinct" (Archives, 155). Cowley renders it as "temple" (Aramaic Papyri, 148). 
first term $(\mathrm{hrm})$ must refer to a more specific cultic object within the sanctuary, even as the last ('ntyhw) apparently names a deity (Anath-Yhw): "Menahem swore by the consecrated cultic utensils or substances, by the sanctuary and by the goddess herself." ${ }^{\prime 6} \mathrm{He}$ compares this practice of swearing by temple paraphernalia with Matt 23:16, in which Jesus criticizes oaths taken by the temple and by the gold of the temple, i.e., a more specific, sacred object within the temple.

TAD B7.2 and B7.3 support the presence of a sacred object within the Yeb temple. It is impossible to prove that this sacred object was, in fact, a cult statue. The oath texts cannot then serve as independent witnesses to the presence of statuary in the Judean Yeb temple. At the same time, taken together with the donation list, they lend indirect but suggestive support to the thesis that Judeans at Yeb may have worshipped Yhwh by a statue.

\section{Conclusion}

No single line of evidence conclusively demonstrates that there was cult statuary in the Judean temple at Yeb. Because the data remains so tantalizingly open-ended, we can expect continued scholarly debate over the nature of the island's Yhw cult. The onus of the present study was to inventory the state of the question and to make a few constructive suggestions. Its primary contributions along the way were: to begin addressing the evidence from the Yeb archives to the question of cult statuary in the first Jerusalem temple; to interpret TAD A4.7/8 afresh; and to revisit other key texts for targeted information about cult statuary. Along these lines, the present study proposed that Yeb was contiguous enough with Judean religion in the homeland that, if statuary were proven to exist at Yeb, it would corroborate its presence in the first Jerusalem temple. It also found that Yedoniah's letter of petition does not allude directly or indirectly to cult statuary; even if Egyptians destroyed or stole cult statuary, the letter's pragmatic and non-theological genre would have prevented acknowledgement of it therein. This study also accepted Knauf and Rohrmoser's reading of the donation list as referring to cult statues in the Yeb temple. Lastly, it interpreted the oath texts as indirect but suggestive indices that there was a statue in the Judean temple at Yeb.

By way of concluding, I agree with Tryggve Mettinger: "one might assume that Yhwh was represented by a massebah in the temple at Elephantine." 67 If

66 Van der Toorn, "Herem-Bethel," 285.

$67 \quad$ No Graven Image, 131. 
this is true, then Graetz's dictum stands in need of amendment. Perhaps after the Persian period, "Judaism [only] hears [its God]." But up until the Persian period, some Judeans in good standing — whom other Judeans might greet as "brothers"68_ may well have shared this in common with "paganism": they, too, saw their God, in the form of a cult statue.

68 E.g., Hananiah to "[my brother] Yedoniah and his colleagues the Judean garrison" in TAD A4.1, line 1. See n. 24 above. 